\title{
Evaluation of Rhipicephalus (Boophilus) microplus (Acari: Ixodidae) resistance to different acaricide formulations using samples from Brazilian properties
}

\author{
Avaliação da resistência de Rhipicephalus (Boophilus) microplus (Acari: Ixodidae) a diferentes formulaçôes \\ acaricidas utilizando amostras de propriedades brasileiras
}

Leandro de Oliveira Souza Higa ${ }^{1}$; Marcos Valério Garcia ${ }^{2}$; Jacqueline Cavalcante Barros²; Wilson Werner Koller²; Renato Andreotti ${ }^{2 *}$

\begin{abstract}
${ }^{1}$ Programa de Pós-graduação em Ciência Animal, Universidade Federal de Mato Grosso do Sul - UFMS, Campo Grande, MS, Brasil
${ }^{2}$ Laboratório de Sanidade Animal, Empresa Brasileira de Pesquisa Agropecuária - Embrapa Gado de Corte, Campo Grande, MS, Brasil
\end{abstract}

Received December 10, 2015

Accepted February 29, 2016

\begin{abstract}
The Rhipicephalus (Boophilus) microplus tick is responsible for considerable economic losses in Brazil, causing leather damage, weight loss and reduced milk production in cattle and results in the transmission of pathogens. Currently, the main method for controlling this tick is using acaricides, but their indiscriminate use is one of the major causes of resistance dissemination. In this study, the adult immersion test (AIT) was used to evaluate resistance in ticks from 28 properties located in five different states (Mato Grosso do Sul, Mato Grosso, Ceará, São Paulo, e Minas Gerais) and the Distrito Federal (DF) of Brazil. The resistance was found in $47.64 \%$ of the repetitions demonstrating an efficacy of less than $90 \%$ in various locations throughout the country. The larvae packet test was used to evaluate samples from ten properties in four states (Mato Grosso do Sul, Mato Grosso, Minas Gerais and Espírito Santo). Spray products belonging to the main classes of acaricides, including combination formulations, were used in both types of test. New cases of resistance were found on properties within the states of Ceará, Espírito Santo and Mato Grosso, where such resistance was not previously reported.
\end{abstract}

Keywords: Cattle tick, Adult Immersion Test, Larvae Packet Test, acaricide resistance.

\section{Resumo}

O carrapato Rhipicephalus (Boophilus) microplus é responsável por consideráveis perdas econômicas no Brasil, causando, nos bovinos, danos ao couro, perda de peso, redução na produçáo de leite, o que resulta na transmissáo também de patógenos. Atualmente, o principal método de controle para esse carrapato é o uso de acaricidas, porém seu uso indiscriminado é uma das principais causas da disseminação da resistência. Neste estudo, o teste de imersão de adultos (TIA) foi utilizado para avaliar a resistência em carrapatos provenientes de 28 propriedades, localizadas em cinco diferentes estados brasileiros (Mato Grosso do Sul, Mato Grosso, Ceará, São Paulo, e Minas Gerais) e no Distrito Federal (DF). A resistência foi encontrada em $47,64 \%$ das repetiçóes, demonstrando uma eficácia de menos de $90 \%$ em vários lugares do país. $\mathrm{O}$ teste de pacote de larva foi utilizado para avaliar amostras de 10 propriedades em quatro estados (Mato Grosso do Sul, Mato Grosso, Minas Gerais e Espírito Santo). Produtos de pulverização, pertencentes às principais classes de acaricidas, incluindo-se associaçóes, foram utilizados em ambos os testes. Novos casos de resistência foram encontrados em propriedades nos estados do Ceará, Espírito Santo e Mato Grosso, nas quais a resistência ainda não havia sido previamente reportada.

Palavras-chave: Carrapato bovino, Teste de Imersão de Adultos, Teste de Pacote de Larvas, resistência acaricida.

\footnotetext{
*Corresponding author: Renato Andreotti. Laboratório de Sanidade Animal, Empresa Brasileira de Pesquisa Agropecuária - Embrapa Gado de Corte, Av. Rádio Maia, 830, Zona Rural, CEP 79106-550, Campo Grande, MS, Brasil. e-mail: renato.andreotti@embrapa.br
} 


\section{Introduction}

Currently, it is estimated that Brazil has approximately 212.8 million bovines and exports approximately 1,5 million tons of carcass annually, thereby holding second place in world-wide meat production (Gazeta Santa Cruz, 2014) and fifth place in milk production (FAO, 2015). However, one of the main obstacles to increasing the profit of the supply chain is the presence of the Rhipicephalus (B.) microplus tick, which occurs throughout intertropical regions and causes economic losses in many countries. According to Grisi et al. (2014), the annual losses in Brazil due to this tick are estimated to be 3.24 billion US dollars.

According to Gomes et al. (2011), in addition to reducing meat and milk production, the skin lesions caused by tick infestation affect leather prices and contribute to the development of myiasis. This ectoparasite has also been associated with the transmission of pathogens, such as Babesia bovis, B. bigemina and Anaplasma marginale (Bovine Babesiosis and Anaplasmosis Complex).

Over decades, many classes of acaricide have been developed and used for tick control. Generally, each class has a different mechanism of action, but the efficacy of each of them is susceptible to the development of resistant tick populations. Resistance is defined as "the ability of a parasite strain to survive and/or to multiply despite the administration and absorption of a drug given in doses equal to or higher than those usually recommended but within the limits of tolerance of the subject" (WHO, 1965).

An integrated program to control ticks and the diseases that they may transmit has already been developed in Africa (YOUNG et al., 1988). However, such a program has not been established in Brazil, and the acaricides to be used in tick control are selected based on non-technical parameters. This selection process, in addition to drug underdosing, are the main factors contributing to the development of resistant populations (FURLONG \& PRATA, 2000) and consequently, the propagation of alleles that confer resistance to the next generations of parasites. Therefore, reports of acaricide resistant $R$. (B.) microplus populations in Brazil, including reports of multiple resistant strains, have become more frequent and have been received from locations throughout the country (HIGA et al., 2015; RECK et al., 2014).

Due to this situation, the objective of this study was to evaluate the current status of the acaricide-resistant $R$. (B.) microplus ticks on different properties in Brazil to help beef and dairy cattle producers choose effective acaricidal products based on the specific resistant tick populations on each property, which can be determined using toxicological bioassays.

\section{Materials and Methods}

Different spray acaricides were evaluated using bioassays to monitor resistance. The efficacy of the tested products was determined using tick samples collected from different locations in the country, according to the guidelines provided on the Embrapa Gado de Corte (2016) website. The samples were generally from producers with bovine tick-infestation problems. The following classes of acaricides were analyzed: pyrethroids, organophosphates, aminidines, and pyrethroid/organophosphate combinations.
Adult Immersion Tests (AIT) using samples from 28 properties located in five states: Mato Grosso do Sul (MS), Mato Grosso (MT), Ceará (CE), São Paulo (SP), Minas Gerais (MG) and the Distrito Federal (DF) were conducted. The samples from Mato Grosso do Sul were from the cities of Anastácio, Aparecida do Taboado, Bela Vista, Campo Grande, Dois Irmãos do Buriti, Dourados, Iguatemi, Jaraguari, Nioaque, Nova Alvorada do Sul, Terenos and Vicentina. The samples from Mato Grosso were from Nova Mutum; the samples from Ceará were from Pacajus; the samples from São Paulo were from Jaboticabal; and the samples from Minas Gerais were from Estrela do Sul. Finally, the samples from the Distrito Federal were from Brasília.

The Larvae Packet Test (LPT) was performed using samples from 10 properties with beef and milk cattle in four states (MS, MT, MG and ES). The samples of larvae and engorged females from the state of Mato Grosso do Sul were from the following cities: Aparecida do Taboado, Campo Grande, Dourados (two properties), Iguatemi (two properties), and Rochedo; those from Mato Grosso were from Brasnorte; those from Minas Gerais were from Monte Carmelo; and those from Espírito Santo were from Montanha.

\section{Adult Immersion Test (AIT)}

For the AITs, engorged females were washed with running water and then were dried with paper towels. Tick aspects such as physical condition, engorgement level and mobility (physical force) were considered to choose what engorged females to test in the experiment. The ticks were weighed and were distributed into groups of 10 specimens (treatment), while maintaining the closest approximate weight of each treatment $( \pm 0.5 \mathrm{~g})$.

All products tested were commercial formulations. Commercial dilutions of each tested product were prepared in disposable bottles containing $200 \mathrm{~mL}$ of water and shaken to homogenize the solution. Each group was submerged in the respective dilution for five minutes. Next, the ticks were removed from the solution and were dried with filter paper. Then, they were allocated in Petri dishes, fixed dorsally using double-sided tape and packed in BOD (Biochemical Oxygen Demand) at $28^{\circ} \mathrm{C}$ with a relative humidity of $80 \%$ (UR) for 14 days. When oviposition was complete, the eggs were allocated in cotton-sealed syringes (cotton plug) and were maintained in BOD for another 10 days. The reproductive parameters (engorged female weight, egg weight, and hatchability rate) were analyzed according to the "Acaricide Efficacy" (AE) protocol described by Drummond et al. (1973). An acaricide product is considered efficacious when the $\mathrm{AE}$ is $\geq 95 \%$.

\section{Larvae Packet Test (LPT)}

The LPT was performed according to the protocol proposed by FAO (2004). Filter papers were impregnated with $700 \mu \mathrm{L}$ of the commercial dilution of each product. After $24 \mathrm{~h}$, approximately $100 R$. (B.) microplus larvae were placed in a container with the impregnated paper, which was subsequently closed with a tab. After $24 \mathrm{~h}$, the mortality and acaricide efficacy were evaluated using the following formula: 


$$
\begin{gathered}
\text { Corrected } \\
\text { mortality } \%
\end{gathered}=\left(\begin{array}{l}
(\% \text { mortality treated }-\% \text { mortality control }) / \\
(100 \%-\% \text { mortality control })
\end{array}\right) \times 100
$$

\section{Results and Discussion}

\section{Acaricide test}

$R$. (B.) microplus specimens from each property were tested using different acaricides belonging to the different classes. Each acaricide tested on a given property was considered a repetition. In this study, 102 of the 212 performed repetitions revealed the presence of resistance in the evaluated population (efficacy of less 90\%). Therefore, as shown in Table 1, the average efficacy of the tested classes of acaricides was $47.64 \%$, which was an unsatisfactory result.

In general, the main chemical classes to which resistance was found were amidines and pyrethroids (Table 1). In 20 of the 29 times that products containing amidines were tested, the acaricide efficacy was less than 90\% (68.9\%). Pyrethroids were tested 49 times and showed an efficacy of less than $90 \% 42$ times (85.6\%). These results demonstrate the broad distribution of resistance to single-base acaricides on the sampled properties.

The acaricides belonging to the organophosphate class that were tested in this study had the following formulations: dichlorvos + chlorfenvinphos + calcium alkylaryl sulfonate $20 \mathrm{~g}+$ xylol and dichlorvos $60 \mathrm{~g}+$ chlorpyrifos $20 \mathrm{~g}$. The results of the 43 tests performed using chemicals in this class showed that efficacy rates of less than $90 \%$ were obtained for specimens from only nine properties. These data suggest that acaricides in this class are effective alternative control chemicals on many properties, which can be confirmed using a specific bioassay.

Regarding combination acaricide formulations, cypermethrin $15 \mathrm{~g}+$ chlorpyrifos $25 \mathrm{~g}+$ citronella $1 \mathrm{~g}+$ piperonyl butoxide $15 \mathrm{~g}$ was highly efficacious, reaching the recommended efficacy in every test that was performed. Formulations with a high concentration of active ingredients can even develop resistance, which consequently fail to control the $R$. (B.) microplus tick.

\section{Pyrethroids}

In this study, resistance (efficacy $\leq 95 \%$ ) to products belonging to the pyrethroid class was found in $R$. (B.) microplus specimens from the states of São Paulo, Ceará, Minas Gerais and on many properties in Mato Grosso do Sul (Tables 2 and 3), with these products exhibiting efficacy ranging from zero to $100 \%$ for the three analyzed active ingredients (alpha-cypermethrin, cypermethrin and deltamethrin). These results confirmed the results obtained by Koller et al. (2009), Gomes et al. (2011) and Mendes et al. (2013) in Mato Grosso do Sul and those obtained by Mendes et al. (2001, 2011) and Pereira (2006) in the state of São Paulo. There are no reports of such resistance in Ceará (HIGA et al., 2015), but it has been reported in other states in the northeastern region of Brazil, including Bahia (CAMPOS \& OLIVEIRA, 2005; RAYNAL et al., 2013) and Pernambuco (SILVA et al., 2005).

Kruskal-Wallis variance analysis was applied to the data regarding the efficacy of the three pyrethroid active ingredients to kill specimens from the various properties, which showed that the efficacy of alpha-cypermethrin was different from that of the cypermethrin formulation $(p<0.05)$ at the same concentration. The average efficacies of alpha-cypermethrin and cypermethrin were $41.89 \%$ and $81.78 \%$, respectively, suggesting that efficacy changes according to a modification in the chemical structure of the drug used in the chosen locations. A second Kruskal-Wallis variance analysis of the data related to these two chemical products was performed, which showed that their effects differed ( $\mathrm{p}<0.05)$.

Synthetic pyrethroids have been used in Brazil since the 1970s, and the first cases of resistance were reported in 1989 (ARANTES et al., 1995). Since then, pyrethroids have been widely used, and no new drugs or combined formulations of active ingredients in the same class have been developed, as was the case for the organophosphates.

\section{Organophosphates}

The acaricidal efficacy of the product with the formulation "DDVP $60 \mathrm{~g}$ + chlorpyrifos $20 \mathrm{~g}$ " was less than $95 \%$ for $R$. (B.) microplus specimens from 6 of the 24 (25\%) properties evaluated, with an average efficacy of $88.13 \%$. These data confirmed the results of Koller et al. (2009) and Gomes et al. (2011), who also tested this product using the "Adult Immersion Test" and found unsatisfactory average efficacies of $85.64 \%$ and $85.28 \%$, respectively.

The formulation "DDVP $60 \mathrm{~g}+$ chlorfenvinphos $20 \mathrm{~g}+$ calcium alkylaryl sulfonate $20 \mathrm{~g}+$ xylol" was also tested, achieving an average efficacy of $91.89 \%$ and found to be ineffective on only two properties (Campo Grande and Nova Alvorada do Sul, both in Mato Grosso do Sul). These results confirm the findings of de

Table 1. Total number of repetitions and number of repetitions demonstrating resistance to various acaricides of different classes, as determined using the Adult Immersion Test.

\begin{tabular}{cccc}
\hline Chemical Class & Total repetitions for each class & $\begin{array}{c}\text { Total repetitions with efficacy of } \\
\text { less than 90\% (resistance) }\end{array}$ & $\begin{array}{c}\text { Percentage of non-effective rep- } \\
\text { etitions for each class }\end{array}$ \\
\hline Association & 91 & 30 & $32.9 \%$ \\
Formamidine & 29 & 20 & $68.9 \%$ \\
Pyrethroid & 49 & 42 & $85.7 \%$ \\
Organophosphate & 43 & 9 & $20.9 \%$ \\
Total & 212 & 101 & $47.64 \%$ \\
Total percentage & $100 \%$ & & \\
\hline
\end{tabular}

Each acaricide product tested on specimens from each property was considered a repetition. 
Table 2. Average efficacy of pyrethroids, organophosphates and aminidines in controlling Rhipicephalus (Boophilus) microplus on various properties, based on samples sent to Embrapa Gado de Corte, as determined using the Adult Immersion Test.

\begin{tabular}{|c|c|c|c|c|c|c|c|}
\hline LOCATION & $\begin{array}{l}\text { Alpha-cyper- } \\
\text { methrin } 15 \mathrm{~g}\end{array}$ & $\begin{array}{l}\text { Cypermethrin } \\
15 \mathrm{~g}\end{array}$ & $\begin{array}{l}\text { Deltamethrin } \\
25 \mathrm{~g}\end{array}$ & $\begin{array}{c}\text { DDVP } 60 \mathrm{~g}+ \\
\text { chlorfenvin- } \\
\text { phos } 20 \mathrm{~g}+\ldots\end{array}$ & $\begin{array}{c}\text { DDVP } 60 \mathrm{~g}+ \\
\text { chlorpyrifos } \\
20 \mathrm{~g}\end{array}$ & Amitraz 25 g & $\begin{array}{c}\text { Formamidine } \\
12.5 \mathrm{~g}\end{array}$ \\
\hline Campo Grande (MS) & 0 & 44.44 & 14.91 & 21.85 & 22.26 & - & 45.18 \\
\hline Campo Grande (MS) & 0 & 67.67 & 12.93 & 100 & 69.40 & - & 81.48 \\
\hline Pacajus (CE) & 54.68 & 77.89 & 82.98 & 100 & 97.89 & - & 57.08 \\
\hline Iguatemi (MS) & 21.81 & 77.72 & 48.69 & 100 & 91.82 & 77.66 & - \\
\hline Jaboticabal (SP) & 54.36 & - & 91.52 & 100 & - & 89.48 & - \\
\hline Campo Grande (MS) & 10.72 & 82.28 & 71.57 & 100 & 97.20 & 50.83 & - \\
\hline Campo Grande (MS) & 16.24 & - & - & 100 & - & 84.60 & - \\
\hline Jaraguari (MS) & 96.10 & - & 75.66 & 100 & - & 100 & - \\
\hline Nioaque (MS) & 91.89 & 96.03 & 86.87 & 100 & - & 87.42 & - \\
\hline Jaraguari (MS) & 44.28 & 81.52 & - & 100 & 88.05 & - & 66.6 \\
\hline Brasília (DF) & 72.70 & 99.69 & 94.30 & 100 & 100 & 90.73 & - \\
\hline Nova Mutum (MT) & 68.70 & - & 47.84 & 100 & 100 & - & - \\
\hline Ponta Porã (MS) & 0 & 50.26 & -92.26 & 100 & 100 & 23.99 & - \\
\hline Terenos (MS) & 92.54 & 100 & 95.15 & 100 & 100 & 100 & 96.52 \\
\hline Campo Grande (MS) & 26.87 & 94.80 & - & 100 & 76.97 & 17.76 & 70.71 \\
\hline Paranaíba (MS) & 22.70 & 100 & 44.35 & 100 & 95.17 & 99.52 & 95.77 \\
\hline
\end{tabular}

Column 5 Product: DDVP (dichlorvos $60 \mathrm{~g}$ ) + chlorfenvinphos $20 \mathrm{~g}+$ calcium alkylaryl sulfonate $20 \mathrm{~g}+$ xylol; Column 6 Product: DDVP + (dichlorvos $60 \mathrm{~g})+$ chlorpyrifos $20 \mathrm{~g}$.

Table 3. Average efficacy of pyrethroids, organophosphates and aminidines in controlling Rhipicephalus (Boophilus) microplus on various properties, based on samples sent to Embrapa Gado de Corte, as determined using the Adult Immersion Test.

\begin{tabular}{|c|c|c|c|c|c|}
\hline LOCATION & $\begin{array}{l}\text { Alpha- cyperme- } \\
\text { thrin } 15 \mathrm{~g}\end{array}$ & Cypermethrin $15 \mathrm{~g}$ & $\begin{array}{c}\text { DDVP } 60 \mathrm{~g}+ \\
\text { chlorfenvinphos } 20 \\
\mathrm{~g}+\ldots\end{array}$ & $\begin{array}{c}\text { DDVP } 60 \mathrm{~g}+ \\
\text { chlorpyrifos } 20 \mathrm{~g}\end{array}$ & $\begin{array}{c}\text { Formamidine } \\
12.5 \mathrm{~g}\end{array}$ \\
\hline Anastácio (MS) & 42.55 & 90.88 & - & 96.3 & - \\
\hline Estrela do Sul (MG) & 0 & - & - & 100 & - \\
\hline Nova Alvorada do Sul (MG) & 79.73 & - & 40.41 & 80.85 & 73.47 \\
\hline Nova Mutum (MT) & - & 2.59 & - & 100 & - \\
\hline Dois Irmãos do Buriti (MS) & - & 44.74 & - & 2.02 & 21.94 \\
\hline Nova Alvorada do Sul (MS) & - & 82.9 & - & 100 & 65.53 \\
\hline Terenos (MS) & - & & - & 100 & 100 \\
\hline Terenos (MS) & - & & - & 98.7 & 11.6 \\
\hline Vicentina (MS) & - & & - & 100 & 68.57 \\
\hline Bela Vista (MS) & - & & - & 100 & 0 \\
\hline Aparecida do Taboado (MS) & - & & - & 98.82 & 91.67 \\
\hline Dourados (MS) & - & & - & 99.75 & 45.62 \\
\hline
\end{tabular}

Column 4 Product: DDVP (dichlorvos $60 \mathrm{~g}$ ) + chlorfenvinphos $20 \mathrm{~g}+$ calcium alkylaryl sulfonate $20 \mathrm{~g}+$ xylol; Column 5 Product: DDVP + (dichlorvos $60 \mathrm{~g})+$ chlorpyrifos $20 \mathrm{~g}$.

Landim et al. (2006), who also identified a location in Uberaba (MG) for which the efficacy of this product was below the recommended level. Koller et al. (2009) and Gomes et al. (2011) also found that a product formulated as "chlorfenvinphos $20 \mathrm{~g}$ " combined with "DDVP 60 g" had a higher efficacy, reaching 97.68 and $100.00 \%$. The positive response due to including this product in some association formulations may be related to the higher efficacy of chlorfenvinphos because its use in other studies led to a higher average efficacy than did association formulations containing chlorpyrifos. A similar result was obtained in the present study. In a study of properties in the state of Goiás, Silva et al. (2000), obtained an average efficacy of 100\% using only chlorfenvinphos, supporting the results of this study.

\section{Aminidines}

Two products containing chemicals in this class were used, which were described in their documentation as "Amitraz $25 \mathrm{~g}$ " and "formamidine $12.5 \mathrm{~g}$ ". The efficacy of the former ranged from 17.76 to $100 \%$, for an average efficacy of $76.02 \%$. The efficacy of the latter acaricide ranged from 0 to $100 \%$, for an average efficacy of $57.89 \%$. 
The differences in the average efficacies of these two products may be due to differences in the concentration of the ingredients, but because they were used on different properties, it is impossible to compare them because their usage histories were most likely different on the different properties. The fact that the efficacy of both products widely varied is consistent with the results described in a literature review prepared by this research team (HIGA et al., 2015), which noted that there are many reports of resistance to aminidines from locations widely distributed throughout the country.

\section{Association formulations}

Based on the data shown in Tables 2 and 3, different acaricides in combination with organophosphates and pyrethroids were tested in this study. However, even though active ingredients from two classes have different mechanisms of action or types of activity in ticks, only one of the association formulations exhibited the recommended efficacy ( $\geq 95 \%$ ) (Tables 4, 5 and 6) for AIT tests. This product had the following formulation: cypermethrin $15 \mathrm{~g}+$ chlorpyrifos $25 \mathrm{~g}+$ citronella $1 \mathrm{~g}+$ piperonyl butoxide $15 \mathrm{~g}$. This result corroborates the findings of Koller et al. (2009), Andreotti et al. (2011), Gomes et al. (2011) and Santana et al. (2013), who found that the combination of cypermethrin chlorpyrifos, and piperonyl butoxide achieved an average efficacy of $100 \%$ in most tests.

The high level of efficacy of this product may be related to the presence of the synergist piperonyl butoxide, which is an agent that potentiates the activity of pyrethroid acaricide, increasing its efficacy. This synergist appears to act on cytochrome P450, which may inhibit the activity of acaricides such as malathion (GUEDES \& ZHU, 1998), and consequently, it is used in

Table 4. Total number of repetitions and number of repetitions demonstrating resistance to different "association" acaricide formulations, as determined using the Adult Immersion Test.

\begin{tabular}{lcc}
\hline \multicolumn{1}{c}{ Chemical base (associations) } & $\begin{array}{c}\text { Number of repetitions demonstrating } \\
\text { resistance/total number of repetitions }\end{array}$ & $\begin{array}{c}\text { Percentage of repetitions demonstrat- } \\
\text { ing resistance relative to the total }\end{array}$ \\
\hline Dichlorvos 45 g + cypermethrin 50 g & $8 / 17$ & 26.6 \\
Cypermethrin 20 g + chlorpyrifos 50 g & $4 / 18$ & 13.3 \\
Cypermethrin 15 g + chlorpyrifos 25 g + Citronella 1 g & $6 / 10$ & 20.0 \\
Cypermethrin 15 g + chlorpyrifos 30 g + Fenthion 15 g & $2 / 9$ & 6.6 \\
Cypermethrin 15 g + chlorpyrifos 25 g +Citronella 1 g + & $0 / 20$ & 0.0 \\
piperonyl butoxide 15g & & 16.6 \\
Ethion 60 g + cypermethrin 8 g & 5 de 7 & 16.6 \\
Cypermethrin 5 g + dichlorvos (DDPV) 45 g & 30 & 100.0 \\
TOTAL RESISTANT & & \\
\hline
\end{tabular}

Table 5. Average efficacy of acaricides formulated with a pyrethroid in association with an organophosphate in controlling Rhipicephalus (Boophilus) microplus on various properties, based on samples sent to Embrapa Gado de Corte, as determined using the Adult Immersion Test (AIT).

\begin{tabular}{|c|c|c|c|c|c|}
\hline LOCATION & $\begin{array}{l}\text { Dichlorvos } 45 \mathrm{~g}+ \\
\text { cypermethrin } 50 \mathrm{~g}\end{array}$ & $\begin{array}{l}\text { Cypermethrin } 20 \mathrm{~g}+ \\
\text { chlorpyrifos } 50 \mathrm{~g}\end{array}$ & $\begin{array}{c}\text { Cypermethrin } 15 \mathrm{~g}+ \\
\text { chlorpyrifos } \\
25 \mathrm{~g}+\text { citronellal } 1 \mathrm{~g}\end{array}$ & $\begin{array}{c}\text { Cypermethrin } 15 \mathrm{~g}+ \\
\text { chlorpyrifos } \\
25 \mathrm{~g}+\text { citronella } 1 \mathrm{~g} \\
+ \text { piperonyl butoxide } \\
15 \mathrm{~g}\end{array}$ & $\begin{array}{c}\text { Ethion } 60 \mathrm{~g}+ \\
\text { cypermethrin } 8 \mathrm{~g}\end{array}$ \\
\hline Campo Grande (MS) & 80.21 & 20.35 & 10.68 & 94.90 & 47.17 \\
\hline Campo Grande (MS) & 89.55 & - & 32.55 & 100 & 36.65 \\
\hline Pacajús (CE) & 89.25 & 78.92 & 95.03 & 100 & 79.47 \\
\hline Iguatemi (MS) & 79.91 & 96.17 & 76.05 & 100 & 90.35 \\
\hline Jaboticabal (SP) & 100 & NT & NT & 100 & 100 \\
\hline Campo Grande (MS) & 100 & 30.54 & 64.53 & 100 & 21.80 \\
\hline Campo Grande (MS) & - & - & - & 100 & - \\
\hline Jaraguari (MS) & 100 & - & - & 100 & 88.60 \\
\hline Nioaque (MS) & 88.34 & 94.22 & 97.23 & - & - \\
\hline Jaraguari (MS) & 76.97 & - & 55.91 & - & - \\
\hline Brasília (DF) & 100 & 99.16 & 99.67 & - & - \\
\hline Nova Mutum (MT) & - & 99.72 & - & - & - \\
\hline Ponta Porã & 90.32 & 86.56 & 89.90 & - & - \\
\hline Terenos (MS) & 100 & 100 & - & - & - \\
\hline Campo Grande (MS) & 70.75 & 100 & - & 100 & - \\
\hline Paranaíba (MS) & 99.59 & 100 & 98.40 & 100 & - \\
\hline
\end{tabular}


Table 6. Average efficacy of acaricides formulated with a pyrethroid in association with an organophosphate in controlling Rhipicephalus (Boophilus) microplus on various properties, based on samples sent to Embrapa Gado de Corte, as determined using the Adult Immersion Test (AIT).

\begin{tabular}{|c|c|c|c|c|c|c|}
\hline LOCATION & $\begin{array}{l}\text { Dichlorvos } 45 \mathrm{~g} \\
+ \text { cypermethrin } \\
50 \mathrm{~g}\end{array}$ & $\begin{array}{c}\text { Cypermethrin } \\
20 \mathrm{~g}+ \\
\text { chlorpyrifos } \\
50 \mathrm{~g}\end{array}$ & $\begin{array}{c}\text { Cypermethrin } \\
15 \mathrm{~g}+ \\
\text { chlorpyrifos } \\
30 \mathrm{~g}+\text { Fenthion } \\
15 \mathrm{~g}\end{array}$ & $\begin{array}{c}\text { Cypermethrin } \\
15 \mathrm{~g}+ \\
\text { chlorpyrifos } 25 \\
\mathrm{~g}+\text { citronella } 1 \\
\mathrm{~g}+\text { piperonyl } \\
\text { butoxide } 15 \mathrm{~g}\end{array}$ & $\begin{array}{l}\text { Cypermethrin } 5 \\
\text { g + chlorpyrifos } \\
7 \mathrm{~g}+\text { piperonyl } \\
\text { butoxide } 1 \mathrm{~mL}\end{array}$ & $\begin{array}{l}\text { Cypermethrin } \\
5 \mathrm{~g}+\text { dichlorvos } \\
\text { (DDVP) } 45 \mathrm{~g}\end{array}$ \\
\hline Anastácio (MS) & 100 & 100 & 91.98 & 100 & - & - \\
\hline Estrela do Sul (MG) & - & 100 & - & 100 & - & - \\
\hline Nova Alvorada do Sul (MS) & 97.97 & 100 & - & 100 & - & - \\
\hline Nova Mutum (MS) & 15.08 & 97.53 & 78.51 & 100 & 100 & - \\
\hline Dois Irmãos do Buriti (MS) & - & - & - & 100 & 100 & - \\
\hline Nova Alvorada do Sul (MS) & - & 100 & 100 & 100 & 100 & 45.93 \\
\hline Terenos (MS) & - & - & 100 & 100 & - & 100 \\
\hline Terenos (MS) & - & - & 100 & 100 & - & 82.32 \\
\hline Vicentina (MS) & - & - & 32.5 & 100 & - & 56.02 \\
\hline Bela Vista (MS) & - & - & 100 & 100 & - & 81.49 \\
\hline Aparecida do Taboado (MS) & - & - & 100 & 100 & - & 92.85 \\
\hline Dourados (MS) & - & - & 100 & 100 & - & 42.77 \\
\hline
\end{tabular}

combination with certain acaricides. In this study, this product was tested on specimens from 21 of the 28 evaluated properties and was found to effective in controlling $R$. (B.) microplus from almost $100 \%$ of the properties (resistance had begun to appear on only one property, with the product having $94.9 \%$ efficacy).

A product with the formulation "cypermethrin $15 \mathrm{~g}+$ chlorpyrifos $25 \mathrm{~g}+$ citronella $1 \mathrm{~g}$ " was also evaluated. This formulation was found to be effective on four of the 10 properties that were analyzed (Table 4) and exhibited an average efficacy of 71.99\%. Another association formulation, "cypermethrin $15 \mathrm{~g}+$ chlorpyrifos $30 \mathrm{~g}+$ fenthion $15 \mathrm{~g}$ ", was effective on seven of nine evaluated properties and exhibited an average efficacy of $89.24 \%$. A Kruskal-Wallis variance test of the results obtained using these two formulations was performed due to their similar contents. This test showed that the effects of the formulations differed $(p<0.05)$, suggesting that the difference may be related to the presence of fenthion instead of citronella $1 \mathrm{~g}$, as well as the increased concentration of chlorpyrifos. This result suggests that citronella may not have a sufficient acaricide effect at this concentration $(1 \mathrm{~g})$ on bovine ticks and that the use of two active ingredients belonging to the organophosphate class in combination with pyrethroids may be an alternative method of tick control.

Another product with a higher concentration of chlorpyrifos was also used in this study (cypermethrin $20 \mathrm{~g}+$ chlorpyrifos $50 \mathrm{~g}$ ), which achieved an average efficacy of $87.69 \%$ and was effective on 10 of the 16 properties were it was evaluated.

\section{Larvae Packet Test}

The result obtained using the LPT, similar to those obtained using the AIT, showed that the association formulations and the organophosphates were more effective than were the other products tested. Resistance to formamidines was found in various locations, and in 9 of 11 properties, its efficacy was not satisfactory $(<95 \%)$ (Table 7$)$.

Using the LPT, resistance to all of the tested active ingredients was found, even resistance to the association formulation "cypermethrin $15 \mathrm{~g}+$ chlorpyrifos $25 \mathrm{~g}+$ Citronella $1 \mathrm{~g}+$ piperonyl butoxide $15 \mathrm{~g}$ " (Table 7), which had demonstrated a satisfactory efficacy using the AIT test. In this specific case, the owner had been using the product for a prolonged period, which demonstrates that resistance to a product that is $100 \%$ effective on other properties can develop if it is used exclusively for a long period.

It was possible to compare the two sets of samples evaluated using the two tests (AIT and LPT), as shown in the table below (Table 5). In the case of samples from Aparecida do Taboado (MS), the adult ticks were more sensitive to the acaricides than were the larvae, which was also observed in samples from a property located in Dourados, MS (Table 8).

\section{Resistance in other Brazilian states}

The tests of ticks in the state of Mato Grosso were conducted using samples from properties located in the city of Nova Mutum. Resistance against the following formulations was found: "alpha-cypermethrin $15 \mathrm{~g}$ and deltamethrin $25 \mathrm{~g}$ "; "dichlorvos $45 \mathrm{~g}$ + cypermethrin $50 \mathrm{~g}$; cypermethrin $15 \mathrm{~g}$ + chlorpyrifos $25 \mathrm{~g}+$ citronella $1 \mathrm{~g}$; cypermethrin $15 \mathrm{~g}$; DDVP (dichlorvos $60 \mathrm{~g}$ ) + chlorpyrifos $20 \mathrm{~g}$ ". It is important to mention that until the beginning of 2015 there were no reports regarding acaricide-resistant ticks in the state of Mato Grosso (HIGA et al., 2015). Acaricide-resistant resistance in ticks is a serious problem for the local beef supply chain because some of the largest herds in Brazil are in Mato Grosso. The situation regarding products in the amidine class is unknown because they have not been tested. However, resistance to pyrethroids, organophosphates and association formulation was found on two properties, which is a sufficient reason for concern. 
Table 7. Evaluation of the efficacy of different acaricides in controlling Rhipicephalus (Boophilus) microplus on various properties, based on samples sent to Embrapa Gado de Corte, as determined using the Larvae Packet Test - LPT.

\begin{tabular}{|c|c|c|c|c|c|c|}
\hline LOCATION & $\begin{array}{c}\text { Cypermethrin } \\
15 \mathrm{~g}+ \\
\text { chlorpyrifos } \\
30 \mathrm{~g}+\text { Fenthion } \\
15 \mathrm{~g}\end{array}$ & $\begin{array}{c}\text { Cypermethrin } \\
15 \mathrm{~g}+ \\
\text { chlorpyrifos } \\
25 \mathrm{~g}+\text { citronella } \\
1 \mathrm{~g}+\text { piperonyl } \\
\text { butoxide } 15 \mathrm{~g}\end{array}$ & $\begin{array}{c}\text { Formamidine } \\
12.5 \mathrm{~g}\end{array}$ & $\begin{array}{l}\text { Cypermethrin } \\
5 \mathrm{~g}+\text { dichlorvos } \\
\text { (DDVP) } 45 \mathrm{~g}\end{array}$ & $\begin{array}{l}\text { Cypermethrin } \\
15 \mathrm{~g}\end{array}$ & $\begin{array}{c}\text { DDVP } \\
\text { (Dichlorvos } \\
60 \mathrm{~g})+ \\
\text { chlorpyrifos } \\
20 \mathrm{~g}\end{array}$ \\
\hline Brasnorte, MT & 100 & 99.46 & 92.64 & 99.64 & & 100 \\
\hline Monte Carmelo, MG & 78.38 & 91.25 & 61.17 & 92.97 & & 93.81 \\
\hline Campo Grande, MS & 99.57 & 100 & 25.86 & 100 & & 100 \\
\hline Rochedo, MS & 100 & 100 & 60.02 & 100 & & 99.78 \\
\hline Montanha, ES & 93.62 & 98.80 & 13.82 & 97.12 & & 68.49 \\
\hline Iguatemi, MS & 94.64 & 98.09 & 20.59 & 94.03 & & 88.93 \\
\hline Aparecida do Ta-boado, MS & 70.77 & 7.13 & 95.84 & 42.53 & & 55.70 \\
\hline Dourados, MS, Mata Azul & 100 & 100 & 91.75 & 93.85 & & 99.75 \\
\hline Dourados, MS, Santa Fé & 98.76 & 98.51 & 89.71 & 55.17 & 78.04 & 88.54 \\
\hline
\end{tabular}

Table 8. Comparison of the efficacy of different acaricides in controlling Rhipicephalus (Boophilus) microplus on two properties in the State of Mato Grosso do Sul, as assessed using the Larvae Packet Test (LPT) and the Adult Immersion Test (AIT).

\begin{tabular}{|c|c|c|c|c|c|c|}
\hline LOCATION & Applied Test & $\begin{array}{c}\text { Cypermethrin } \\
15 \mathrm{~g}+ \\
\text { chlorpyrifos } \\
30 \mathrm{~g}+\text { Fenthion } \\
15 \mathrm{~g}\end{array}$ & $\begin{array}{c}\text { Cypermethrin } \\
15 \mathrm{~g}+ \\
\text { chlorpyrifos } \\
25 \mathrm{~g}+\text { citronella } \\
1 \mathrm{~g}+\text { piperonyl } \\
\text { butoxide } 15 \mathrm{~g} \\
\end{array}$ & $\begin{array}{l}\text { Formamidine } \\
12.5 \mathrm{~g}\end{array}$ & $\begin{array}{l}\text { Cypermethrin } \\
5 \mathrm{~g}+\text { dichlorvos } \\
\text { (DDVP) } 45 \mathrm{~g}\end{array}$ & $\begin{array}{c}\text { DDVP } \\
\text { (dichlorvos } 60 \mathrm{~g} \text { ) } \\
+ \text { chlorpyrifos } \\
20 \mathrm{~g}\end{array}$ \\
\hline \multirow[t]{2}{*}{ Aparecida do Taboa-do, MS } & LPT & 70.77 & 7.13 & 95.84 & 42.53 & 55.7 \\
\hline & AIT & 100 & 100 & 91.67 & 92.85 & 98.82 \\
\hline \multirow[t]{2}{*}{ Dourados, Mata Azul, MS } & LPT & 100 & 100 & 91.75 & 93.85 & 99.75 \\
\hline & AIT & 100 & 100 & 45.62 & 42.77 & 99.75 \\
\hline
\end{tabular}

Ticks resistant to the product "alpha-cypermethrin $15 \mathrm{~g}$ " were found on a property in Brasília, which is also in the mid-western region of the country. This result confirms results obtained in Goiás, where only pyrethroids had efficacy below the recommended level (SILVA et al., 2000; FERNANDES, 2001).

Tests of samples from Pacajús, in Ceará, revealed the existence of a tick population resistant to many acaricides, including pyrethroids and amitraz. The products that did not achieve the desired efficacy in the evaluations had the following formulations: "dichlorvos $45 \mathrm{~g}+$ cypermethrin $50 \mathrm{~g}$; cypermethrin $20 \mathrm{~g}+$ chlorpyrifos $50 \mathrm{~g}$; ethion $60 \mathrm{~g}+$ cypermethrin $8 \mathrm{~g}$; alpha-cypermethrin $15 \mathrm{~g}$; cypermethrin $15 \mathrm{~g}$; deltamethrin $25 \mathrm{~g}$ and formamidine $12.5 \mathrm{~g}$ ". This is the first report of an acaricide resistant tick population in the state of Ceará.

Acaricide-resistant ticks were found in the municipality of Jaboticabal, state of São Paulo, but they were resistant only to products belonging to both pyrethroid and aminidine classes, confirming what was previously observed by Mendes et al. (2011).

On one property in the municipality of Terenos, MS, a strain that was sensitive to all of the classes of acaricide was found, whereas on another property that is close to the first one, ticks resistant to one combination formulation (cypermethrin $5 \mathrm{~g}+$ dichlorvos $45 \mathrm{~g}$ ) and to amitraz (Tables 2, 3 and 5) were found. These results support the proposition that each producer who is worried about having an efficient control system needs technical guidance based on the results of resistance bioassays to choose the product appropriate for the property. This study showed that there is acaricide resistance in tick populations in places from which resistance has not been reported (Ceará, Espírito Santo and Mato Grosso). The results of this study also demonstrated that an increasing number of association formulations have an efficacy below the recommended level. Finally, considering that it has become harder to develop new effective acaricide molecules, it is necessary to focus technical and research efforts on identifying products that are effective in controlling $R$. (B.) microplus on a given property and to investigate alternative control methods using different techniques, such as molecular biological methods.

\section{Final Considerations}

Due to the spread of acaricide-resistant ticks into properties throughout Brazil, performing bioassay-based resistance diagnoses is extremely important. Knowing which chemical is effective on each property, in addition to being the first step in creating a control strategy, is a highly applicable low-cost strategy for controlling $R$. (B.) microplus. The results of such tests also facilitate the correct usage of acaricides with the objective of maintaining their efficacy (CORDOVÉS et al., 2001) because the development of new 
molecules with acaricide activity is very expensive. In addition, bioassays are more amenable to the producers than are tests based on molecular assays, such as PCR.

Because the molecular and biochemical aspects of drugs of the pyrethroid and organophosphate classes are better understood (GUERRERO et al., 2012; ABBAS et al., 2014), toxicological bioassays (pour on and pulverization) of all of the main classes of these acaricides, including organophosphates, pyrethroids, aminidines, macrocyclical lactones, phenylpyrazoles and fluazuron (growth inhibitor) (FURLONG et al., 2007) will allow phenotypical diagnoses of tick populations.

\section{References}

Abbas RZ, Zaman MA, Colwell DD, Gilleard J, Iqbal Z. Acaricide resistance in cattle ticks and approaches to its management: The state of play. Vet Parasitol 2014; 203(1-2): 6-20. http://dx.doi.org/10.1016/j. vetpar.2014.03.006. PMid:24709006.

Andreotti R, Guerrero FD, Soares MA, Barros JC, Miller RJ, León AP. Acaricide resistance of Rhipicephalus (Boophilus) microplus in State of Mato Grosso do Sul, Brazil. Rev Bras Parasitol Vet 2011; 20(2): 127-133. http:// dx.doi.org/10.1590/S1984-29612011000200007. PMid:21722487.

Arantes GJ, Marques AO, Honer MR. O carrapato bovino, Boophilus microplus no município de Uberlândia, MG: análise da sua resistência contra carrapaticidas comerciais. Rev Bras Parasitol Vet 1995; 4(2): 89-93.

Campos DA Jr, Oliveira PR. Avaliação in vitro da eficácia de acaricidas sobre Boophilus microplus (Canestrini, 1887) (Acari: Ixodidae) de bovinos no município de Ilhéus, Bahia, Brasil. Cienc Rural 2005; 35(6): 13861392. http://dx.doi.org/10.1590/S0103-84782005000600025.

Cordovés CO, Lopez DP, Dias MM. Fundamento e manejo para retardar a resistência de Boophilus microplus e Haematobia irritans no continente americano. Hora Vet 2001; 21(124): 37-44.

Drummond RO, Ernst SE, Trevino JL, Gladney WJ, Graham $\mathrm{OH}$. Boophilus annulatus and B. microplus: laboratory tests of insecticides. J Econ Entomol 1973; 66(1): 130-133. http://dx.doi.org/10.1093/ jee/66.1.130. PMid:4690254.

Embrapa Gado de Corte. Controle do carrapato em Mato Grosso do Sul [online]. [cited 2016 Jan 4]. Available from: http://cloud.cnpgc.embrapa. br/controle-do-carrapato-ms/coleta-e-envio-de-materiais/

Fernandes FF. Efeitos toxicológicos e resistência a piretróides em Boophilus microplus de Goiás. Arq Bras Med Vet Zootec 2001; 53(5): 538-543. http:// dx.doi.org/10.1590/S0102-09352001000500004.

Food and Agriculture Organization of the United Nations - FAO. Resistance management and integrated parasite control in ruminants: guidelines. Module 1. Ticks: acaricide resistance: diagnosis, management and prevention [online]. 2004. p. 25-77 [cited 2016 Jan 4]. Available from: ftp://ftp.fao.org/docrep/fao/010/ag014e/ag014e05.pdf

Food and Agriculture Organization of the United Nations - FAO. Dairy production and products [online]. 2015 [cited 2016 Jan 4]. Available from: http://www.fao.org/agriculture/dairy-gateway/milk-production/ en/\#.VdpAxflViko

Furlong J, Martins JR, Prata MCA. O carrapato dos bovinos e a resistência: temos o que comemorar? Hora Vet 2007; 27(159): 1-7.
Furlong J, Prata MCA. Resistência dos carrapatos aos carrapaticidas: instruçấo técnica para o produtor de leite. Juiz de Fora: Embrapa Gado de Leite; 2000. 34 p.

Gazeta Santa Cruz. ANUALPEC: anuário brasileiro da pecuária: consultancy and information in agribusiness. Santa Cruz do Sul: Editora Gazeta; 2014.

Gomes A, Koller WW, Barros ATM. Suscetibilidade de Rhipicephalus (Boophilus) microplus a carrapaticidas em Mato Grosso do Sul, Brasil. Cienc Rural 2011; 41(8): 1447-1452. http://dx.doi.org/10.1590/S010384782011005000105 .

Grisi L, Leite RC, Martins JRS, Barros ATM, Andreotti R, Cançado $\mathrm{PH}$, et al. Reassessment of the potential economic impact of cattle parasites in Brazil. Rev Bras Parasitol Vet 2014; 23(2): 150-156. http:// dx.doi.org/10.1590/S1984-29612014042. PMid:25054492.

Guedes RNC, Zhu KY. Characterization of malathion resistance in Mexican population of Rhizopertha dominica. Pestic Sci 1998; 53(1): 1520. http://dx.doi.org/10.1002/(SICI) 1096-9063(199805)53:1<15::AIDPS746>3.0.CO;2-Q.

Guerrero FD, Lovis L, Martins JR. Acaricide resistance mechanisms in Rhipicephalus (Boophilus) microplus. Rev Bras Parasitol Vet 2012; 21(1): 1-6. http://dx.doi.org/10.1590/S1984-29612012000100002. PMid:22534937.

Higa LOS, Garcia MV, Barros JC, Koller WW, Andreotti R. Acaricide resistance status of the Rhipicephalus microplus in Brazil: a literature overview. Med Chem 2015; 5(7): 326-333.

Koller WW, Gomes A, Barros ATM. Diagnóstico da resistência do carrapatodo-boi a carrapaticidas em Mato Grosso do Sul. Campo Grande: Embrapa Gado de Corte; 2009.47 p. Boletim de Pesquisa e Desenvolvimento, no. 25.

Landim VJC, Silva EA, Paes JMV, Fernandes LO, Couto GS, Fidalgo EL, et al. Diagnosis of the situation of the resistance of the tick Boophilus microplus the acaricides in beef and dairy cattle in the region of Uberaba. FAZU em Revista 2006; 3: 63-69.

Mendes EC, Mendes MC, Sato ME. Diagnosis of amitraz resistance in brazilian populations of Rhipicephalus (Boophilus) microplus (Acari: Ixodidae) with larval immersion test. Exp Appl Acarol 2013; 61(3): 357 369. http://dx.doi.org/10.1007/s10493-013-9697-3. PMid:23620418.

Mendes MC, Lima CKP, Nogueira AHC, Yoshihara E, Chiebao DP, Gabriel $\mathrm{FH}$, et al. Resistance to cypermethrin, deltamethrin and chlorpyriphos in populations of Rhipicephalus (Boophilus) microplus (Acari: Ixodidae) from small farms of State of São Paulo, Brazil. Vet Parasitol 2011; 178(3-4): 383388. http://dx.doi.org/10.1016/j.vetpar.2011.01.006. PMid:21306827.

Mendes MC, Silva MX, Bracco JE. Teste bioquímico para determinar a resistência de duas cepas do carrapato Boophilus microplus (Canestrini, 1887). Rev Bras Parasitol Vet 2001; 10(2): 61-65.

Pereira JR. Eficácia in vitro de formulaçóes comerciais de carrapaticidas em teleóginas de Boophilus microplus coletadas de bovinos leiteiros do Vale do Paraíba, Estado de São Paulo 2006. Rev Bras Parasitol Vet 2006; 15(2): 45-48. PMid:16834895.

Raynal JT, Silva AAB, Sousa TJ, Bahiense TC, Meyer R, Portela RW. Acaricides efficiency on Rhipicephalus (Boophilus) microplus from Bahia State North-Central region. Rev Bras Parasitol Vet 2013; 22(1): 71-77. http://dx.doi.org/10.1590/S1984-29612013005000006. PMid:23538503.

Reck J, Klafke GM, Webster A, Dall'Agnol B, Scheffer R, Souza UA, et al. First report of fluazuron resistance in Rhipicephalus microplus: A field tick population resistant to six classes of acaricides. Vet Parasitol 2014 201(1-2): 128-136. http://dx.doi.org/10.1016/j.vetpar.2014.01.012. PMid:24560364. 
Santana BS, Ramos AN, Santana MA, Alves LC, Carvalho GA. Susceptibility of Rhipicephalus (Boophilus) microplus (Acari: Ixodidae) to pyrethroids and their associations in Pernambuco, Brazil. Rev Bras Parasitol Vet 2013; 22(2): 276-280. http://dx.doi.org/10.1590/S1984-29612013000200047. PMid:23856731.

Silva MCL, Sobrinho RN, Linhares GFC. Avaliação in vitro da eficácia do clorfenvinfós e da cialotrina sobre o Boophilus microplus, colhidos em bovinos da bacia leiteira da microrregião de Goiânia - Goiás. Cienc Anim Bras 2000; 1(2): 143-148.

Silva WW, Athayde ACR, Araújo GMB, Santos VD, Silva Neto AB. Resistência de fêmeas ingurgitadas de Boophilus microplus e Rhipicephalus sanguineus (ACARI: IXODIDAE) a carrapaticidas no semi-árido paraibano: efeito da cipermetrina e do amitraz. Agropec Cient Semi-árido 2005; 1: 59-62.

World Health Organization - WHO. Resistance of Malaria parasites to drugs [online]. Geneva; 1965. p. 29. Technical Report Series, no. 296 [cited 2016 Jan 4]. Available from: https://extranet.who.int/iris/restricted/ handle/10665/40615

Young AS, Groocock CM, Kariuki DP. Integrated control of ticksand tick-borne diseases of cattle in Africa. Parasitology 1988; 96(2): 403432. http://dx.doi.org/10.1017/S0031182000058388. PMid:3287285. 